\title{
Pusat Arsip di Era Digital: Dilema antara Urgensi dan Relevansi
}

\author{
Indah Novita Sari ${ }^{\mathbf{*}}$; Widiatmoko Adi Putranto ${ }^{1}$; Lastria Nurtanzila ${ }^{1}$ \\ ${ }^{1}$ Program Studi Pengelolaan Arsip dan Rekaman Informasi, Sekolah Vokasi, Universitas Gadjah Mada \\ *Korespondensi: indah.novita.s@mail.ugm.ac.id
}

\begin{abstract}
The problem of records centers in the digital era lies in the inadequate condition of records centers especially in public institutions. Moreover, the emergence of electronic records expose new challenge for many institutions.. This research focuses on the issues of the urgency and relevance of records centers in the digital age. This research is conducted as an effort to save the records and archives in various storage formats that will be useful as historical evidence for future generations. We used qualitative method, and the data was collected from 21 government institutions in Yogyakarta. The results show that there are security and retrieval issues from those observed government institutions. Improper records storage management in general, where records are placed in inadequate warehouses was one of the main problems. On the other hand, technology developments pose new challenges in managing storage, so archivists need to plan data centers. Thus, archivists are in a difficult position facing conventional records management issues and planning electronic data storage. Preserving archives in various formats needs to be prepared, both the records center and the data center. An archive repository that can accommodate various formats and agencies' needs will positively impact the government's performance to deliver its services for the public.
\end{abstract}

Keywords: archives management; records management; data center; government institutions

\begin{abstract}
Abstrak
Permasalahan pusat arsip di era digital menjadi menarik untuk diulas mengingat kondisi pusat arsip di instansi publik yang belum memadai dan kemunculan arsip elektronik sebagai tantangan baru dalam dunia kearsipan. Tema penelitian yang diangkat memang sedikit berbeda dengan penelitian sebelumnya yang lebih banyak mengkaji sarana prasarana tempat penyimpanan arsip dinamis inaktif pada instansi. Penelitian ini berfokus pada dilema urgensi dan relevansi pusat arsip di era digital. Penelitian ini dilakukan sebagai upaya penyelamatan arsip dalam berbagai format penyimpanan yang akan berguna sebagai bukti historis bagi generasi akan datang. Metode penelitian yang digunakan dalam penelitian ini adalah kualitatif deskriptif dengan setting penelitian pada 21 instansi publik di Yogyakarta. Penulis menemukan bahwa terdapat masalah keamanan dan temu kembali arsip pada instansi publik yang di observasi. Hal ini merupakan dampak dari kurang sesuainya manajemen penyimpanan arsip secara umum, dimana arsip diletakkan pada pusat arsip, gudang dan basement yang kurang memadai. Di sisi lain, perkembangan teknologi memunculkan tantangan baru dalam pengelolaan tempat penyimpanan, sehingga arsiparis perlu merencanakan pusat data. Arsiparis berada dalam posisi sulit dikarenakan masih harus meneyelesaikan permasalahan arsip konvensional, sehingga perencanaan pusat data arsip elektronik. Pada akhirnya, penyelamatan arsip dalam berbagai format perlu dipersiapkan, baik pusat arsip maupun pusat data. Tempat penyimpanan arsip yang dapat mengakomodir berbagai format dan kebutuhan instansi, akan berdampak positif bagi kelancaran tugas sehari-hari pada instansi pemerintah dan layanan kepada publik.
\end{abstract}

Kata Kunci: manajemen arsip; pusat data; instansi publik; tempat penyimpanan arsip

\section{PENDAHULUAN}

Isu mengenai pusat arsip mengemuka dan menjadi perbincangan hangat di ruang publik pada akhir tahun 2019 hingga awal tahun 2020. Menteri BUMN membatalkan rencana pembangunan gedung arsip BUMN. Beliau menilai bahwa pembangunan gedung berpotensi membuang anggaran karena perubahan media simpan informasi yang dapat disimpan pada iCloud hingga isu pemindahan ibu kota (Idris, 2019). Permasalahan mengenai pusat arsip yang mengemuka di ruang publik, menarik perhatian sebagian orang dan pemerhati kearsipan. Oleh karena itu, studi yang mengkaji tentang urgensi dan relevansi pusat arsip di era digital, khususnya instansi pemerintah, menjadi penting dilakukan dengan berbagai pertimbangan.

Pertama, karena pusat arsip menjadi bagian krusial dalam usaha pengelolaan dan penyelamatan arsip secara keseluruhan. Kedua, kebijakan yang mengatur standar sarana dan 
prasarana (termasuk pusat arsip) telah ada dan berlaku di Indonesia (Keputusan Kepala ANRI no. 3 tahun 2000) serta Internasional (International Standard Organization 15489:2016), namun implementasinya masih menuai permasalahan tersendiri. Ketiga, studi yang mengkaji dan memahami infrastruktur (pusat arsip) di era digital, belum banyak dilakukan di Indonesia. Berbagai studi yang berhubungan dengan pusat arsip, umumnya membahas sarana prasarana, manajemen, dan proses temu kembali informasi pada arsip konvensional.

Beberapa studi terdahulu terkait pusat arsip dan sarana simpan arsip dilakukan oleh (Jumiyati, 2011) dan (Ramanda \& Indrahti, 2015). Peneliti membahas secara spesifik terkait pusat arsip dan sarana simpan arsip di Pusat Teknologi Bahan Bakar Nuklir dan Pusat Arsip Politeknik Negeri Semarang. Hasil dari kajian yang dilakukan oleh (Jumiyati, 2011) menemukan bahwa sarana dan prasarana kearsipan yang ada di Pusat Teknologi Bahan Bakar Nuklir tergolong belum memadai. Hal ini menimbulkan dampak dalam proses pencarian arsip. Hal senada juga diungkapkan oleh (Ramanda \& Indrahti, 2015) yang menemukan kendala terkait ruang penyimpanan di Pusat Arsip Politeknik Negeri Semarang. Kajian ini mencoba memahami lebih mendalam mengenai permasalahan pusat arsip dan tantangan yang harus dihadapi kedepannya dalam penyelamatan arsip pada era digital.

Pusat arsip memiliki peran besar sebagai tempat penyimpanan yang aman, juga mendukung kelancaran arus arsip yang ada di organisasi. Hal ini karena arsip yang digunakan dalam frekuensi sering (aktif) akan terpisah dengan arsip yang frekuensi penggunaannya menurun (inaktif), sehingga mempermudah dan menghemat waktu dalam pencarian arsip aktif. Selain itu, arsip yang telah habis masa retensinya dapat terkoordinir dengan baik ketika pemusnahan maupun penyerahan ke lembaga kearsipan. (Patricia C. Franks, 2013) menjelaskan beberapa kepentingan dari pusat arsip yaitu "memberikan ruang tambahan untuk arsip aktif, mengurangi kemungkinan kesalahan pemberkasan, meningkatkan layanan arsip inaktif, meningkatkan efisiensi dalam pemusnahan arsip dan menghindari pembelian peralatan penyimpanan yang mahal (misalnya filing cabinet)."

Berbagai kepentingan pusat arsip, memunculkan idealisme bahwa prasarana ini seharusnya dikelola dengan memadai oleh organisasi. Pada kenyataannya, terdapat pusat arsip yang dikelola dengan seadanya. Bahkan terdapat organisasi yang memilih menanggung resiko dengan tidak memiliki pusat arsip. Permasalahan yang berhubungan dengan pusat arsip, tidak hanya terjadi di Indonesia, tetapi juga dihadapi oleh beberapa negara lainnya termasuk Korea Selatan dan Amerika. Peneliti yang mengkaji masalah pengelolaan arsip di Korea Selatan yaitu (Kwak KunHong, 2011) mengungkapkan bahwa sumber utama masalah pengelolaan arsip dinamis adalah pusat arsip di lembaga pemerintah Korea Selatan gagal bekerja secara efisien akibat dikelola pada ruang yang tidak memadai. Hal senada juga diungkapkan oleh (Mark dalam Sari, 2017) bahwa arsip dinamis inaktif biasanya disimpan dalam lemari, ruang bawah tanah, loteng, gudang penyimpanan, unit penyimpanan sewaan atau dimana saja ruang yang tersedia. Di Indonesia, permasalahan yang berhubungan dengan pengelolaan pusat arsip sebagian disebabkan karena “...masih banyak instansi pemerintah maupun swasta yang belum menaruh perhatian secara proporsional terhadap penyimpanan maupun pengelolaan arsip inaktif. Arsip inaktif sering dianggap sebagai barang yang sudah tidak bernilai guna lagi, sehingga ditumpuk pada gudang yang bercampur dengan barang-barang nonarsip” (Arsip Universitas Gadjah Mada, 2014).

Belum usai permasalahan mengenai pusat arsip untuk arsip konvensional, manajemen aersip dihadapkan pada tantangan baru yang muncul akibat inovasi teknologi informasi. Rekaman informasi mengalami transisi bentuk yang merubah cara orang menciptakan, mengelola dan menyimpan informasi. Data dan arsip elektronik menimbulkan tantangan baru dalam pengelolaan dan penyediaan infrastruktur digital. International Standard Organization (ISO) 15489-1:2016 menyebutkan bahwa "arsip, yang terdiri dari format atau media apapun, seharusnya disimpan 
dengan cara tertentu yang melindungi arsip dari penyalahgunaan akses, perubahan, kehilangan maupun kerusakan, termasuk pencurian dan bencana." Arsip dalam bentuk elektronik memerlukan tempat penyimpanan khusus yang disebut pusat data. Pada akhirnya, peran baru perlu ditunjukkan oleh pusat arsip untuk mempertahankan relevansi di era digital. Disamping itu, arsiparis perlu mencari solusi untuk pemeliharaan arsip pada media sebelumnya. Hal ini juga diungkapkan oleh (Cox, 2011) bahwa arsiparis harus melanjutkan tugas pengelolaan arsip di era digital dan menemui tantangan baru dalam melakukan preservasi pada dokumen yang bernilai sejarah.

Studi ini dilakukan untuk meneliti dan memahami situasi problematik yang dihadapi pengelola informasi di pusat arsip, terutama tentang urgensi dan relevansi di era digital. Secara spesifik, tujuan dari penelitian ini adalah untuk mengetahui bagaimana kondisi pusat arsip pada lembaga publik yang ada di Yogyakarta, merefleksikan kepentingan pusat arsip di era digital dan memahami elemen yang perlu dipersiapkan pengelola informasi untuk menyongsong perubahan pusat arsip di era digital.

Untuk mencapai ketersediaan infrastruktur dan pusat arsip yang ideal pada lembaga publik, tentu bukanlah hal yang mudah. Kompleksitas masalah pengarsipan di Indonesia menyumbang keraguan akan apa yang seharusnya dilakukan. Kajian ini merupakan salah satu upaya untuk memahami berbagai masalah pusat arsip, agar kemudian dapat disusun pemecahan yang konkrit untuk penyelamatan arsip pada berbagai media. Dari segi praktis, penelitian ini penting dilakukan karena dua alasan pokok. Pertama, pengelolaan kearsipan telah diamanatkan oleh UndangUndang no. 43 tahun 2009, sehingga setiap bentuk pengabaian terhadap arsip perlu diminimalisir dan ditiadakan. Kedua, upaya penyelamatan arsip tidak dapat ditunda lagi mengingat volume arsip akan terus bertambah. Fenomena banjir informasi, ledakan informasi hingga big data akan menambah kompleksitas masalah penyimpanan informasi. Kajian ini diharapkan memberikan kontribusi lebih luas dalam penyelamatan arsip, agar tetap dapat terakses dari generasi ke generasi.

\section{METODE PENELITIAN}

Metode penelitian yang digunakan dalam penelitian ini adalah kualitatif. Pendekatan ini dipilih karena dirasa cocok untuk menggambarkan pusat arsip, namun dapat mengkaji lebih dalam terhadap topik yang spesifik yaitu pusat arsip di era digital. (Bungin, 2015) menjelaskan bahwa deskriptif kualitatif bertujuan untuk menggambarkan, meringkaskan berbagai kondisi, atau berbagai fenomena realitas yang ada di masyarakat yang menjadi objek penelitian, dan berupaya menarik realitas ke permukaan sebagai suatu ciri, karakter, sifat, model, tanda atau gambaran tentang kondisi, situasi ataupun fenomena tertentu. Gambaran kondisi pusat arsip secara umum diharapkan dapat terungkap dengan menggunakan metode ini, namun tetap dapat mengeksplorasi topik spesifik yang menarik.

Obyek penelitian dilakukan pada 21 Satuan Kerja Perangkat Daerah tingkat kota dan Provinsi yang ada di Daerah Istimewa Yogyakarta dengan sistem acak. Satuan Kerja Perangkat Daerah yang terpilih adalah sebagai berikut:

1. Dinas Komunikasi, Informatika dan Persandian;

2. Dinas Pemberdayaan Masyarakat, Perempuan, dan Perlindungan Anak Kota Yogyakarta;

3. Dinas Kebudayaan Kota Yogyakarta;

4. Dinas Perhubungan Kota Yogyakarta;

5. Biro Organisasi Pemerintahan Provinsi DIY;

6. Badan Kepegawaian Daerah Provinsi DIY;

7. Dinas Pendidikan Kota Yogyakarta;

8. Biro Tata Pemerintahan Setda DIY; 
9. Badan Pemberdayaan Perempuan dan Masyarakat Provinsi DIY;

10. Dinas Kependudukan dan Pencatatan Sipil Kota Yogyakarta;

11. Sekretriat Daerah Provinsi DIY;

12. Dinas Pekerjaan Umum, Perumahan dan Kawasan Permukiman Yogyakarta;

13. Dinas Pertanian dan Pangan Kota Yogyakarta;

14. Biro Administrasi Perekonomian dan Sumber daya Alam Setda DIY;

15. Dinas Kesehatan Kota Yogyakarta;

16. Dinas Lingkungan Hidup dan Kehutanan Yogyakarta;

17. Dinas Perindustrian dan Perdagangan Daerah Istimewa Yogyakarta;

18. Dinas Pariwisata DIY;

19. Dinas Kebudayaan Daerah Istimewa Yogyakarta;

20. Dinas Tenaga Kerja dan Transmigrasi DIY;

21. Satuan Polisi Pamong Praja DIY

Instansi yang terpilih diobservasi secara umum terkait pusat arsip dan infrastruktur yang digunakan. Pendalaman lanjutan terhadap topik spesifik yang terkait infrastruktur digital dilakukan pada 3 SKPD terpilih yaitu Biro Organisasi Pemerintahan, Sekretariat Daerah dan Badan Kepegawaian Daerah Provinsi DIY.

Metode pengumpulan data dilakukan dengan observasi, wawancara dan studi pustaka. Pada proses observasi di 21 SKPD, penulis dibantu oleh mahasiswa angkatan 2016 dan 2017 yang mengikuti mata kuliah "manajemen record center." Pengumpulan data dilakukan selama 2 tahun terakhir yaitu 2018 dan 2019. Informan dipilih secara purposive dimana informan yang dirasakan memiliki kapasitas dan kapabilitas akan diwawancara lebih lanjut. Jenis data dan metode yang digunakan terangkum dalam tabel 1.

Tabel 1

Jenis Data dan Metode Penelitian

\begin{tabular}{|c|c|c|c|c|}
\hline No. & Sumber data & Jenis data & Metode & Data yang dibutuhkan. \\
\hline \multirow[t]{3}{*}{1.} & $\begin{array}{l}21 \quad \text { SKPD di Provinsi } \\
\text { Daerah Istimewa }\end{array}$ & Primer & $\begin{array}{l}\text { Observasi } \\
\text { lapangan, } \\
\text { Wawancara. }\end{array}$ & $\begin{array}{ll}\text { a. Data } & \text { tentang } \\
\text { pengelolaan } & \text { arsip di } \\
\text { SKPD } & \end{array}$ \\
\hline & & & & $\begin{array}{l}\text { b. Informasi kebutuhan } \\
\text { pusat arsip di SKPD } \\
\text { terkait }\end{array}$ \\
\hline & & & & $\begin{array}{lrr}\text { c. Informasi } & \text { tentang } \\
\text { program } & \text { pelestarian } \\
\begin{array}{l}\text { arsip } \\
\text { tersebut. }\end{array} & \text { SKPD } \\
& \end{array}$ \\
\hline \multirow[t]{3}{*}{2.} & $\begin{array}{l}\text { BPS, Perpustakaan, } \\
\text { Literatur yang berkaitan. }\end{array}$ & Sekunder & $\begin{array}{l}\text { Analisis dan } \\
\text { pengelompokan }\end{array}$ & $\begin{array}{l}\text { a. Pengelolaan arsip di } \\
\text { instansi pemerintahan }\end{array}$ \\
\hline & & & 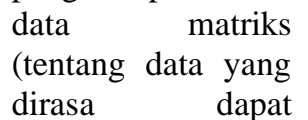 & $\begin{array}{l}\text { b. Manajemen Record } \\
\text { Center }\end{array}$ \\
\hline & & & $\begin{array}{l}\text { mendukung hasil } \\
\text { penelitian) }\end{array}$ & $\begin{array}{l}\text { c. Program Pelestarian } \\
\text { Arsip. }\end{array}$ \\
\hline
\end{tabular}

Data primer dan sekunder yang telah terkumpul kemudian dianalisis berdasarkan metode yang telah dipilih yaitu deskriptif kualitatif. (Seiddel dalam Bungin, 2015) menjelaskan 4 tahapan dalam analisis data kualitatif. "Pertama, mencatat dan memberi kode agar sumber data dapat ditelusuri. Kedua, mengumpulkan, memilah-milah, mengklasifikasikan, menyintesiskan, membuat ikhtisar dan indeks. Ketiga, membuat agar kategori data mempunyai makna, mencari 
dan menemukan pola dan hubungan. Keempat, membuat temuan umum." Penulis melakukan beberapa proses yaitu mencatat dan membuat transkrip, mereduksi data dan mengelompokkan data yang akan dijadikan pembahasan serta menganalisis untuk menghasilkan temuan.

\section{HASIL DAN PEMBAHASAN}

\section{Urgensi dan Kondisi Pusat Arsip pada Lembaga Publik di Yogyakarta}

Dilema muncul akibat situasi problematis yang harus dihadapi oleh para pengelola informasi di era digital. Di satu sisi, pengelolaan arsip konvensional masih menemui hambatan dan kendala yang belum terpecahkan. Disisi yang lain, pengelolaan arsip digital mendesak untuk dilakukan segera, mengingat kepentingan dan pertumbuhan arsipnya yang sangat cepat. Fakta ini dapat menjadi dilema bagi sebagian besar arsiparis dan pengelola informasi di Indonesia. Mereka berada dalam pilihan antara mengabaikan pengelolaan arsip konvensional dan melakukan pengelolaan arsip elektronik atau berupaya keras menyelesaikan permasalahan pengelolaan arsip konvensional sembari bersiap menghadapi tantangan selanjutnya dalam pengelolaan arsip elektronik.

Arsiparis dan pengelola informasi perlu melakukan refleksi untuk memahami bagaimana posisi organisasi mereka dalam pengelolaan arsip secara keseluruhan. Ketersediaan infrastruktur, sumber daya manusia, sistem, prosedur dan kebijakan menjadi indikator penting dalam penentuan langkah strategis dalam pengelolaan arsip (baik konvensional maupun elektronik). Salah satu prasarana yang dibutuhkan untuk pengelolaan yaitu pusat arsip. Berdasarkan observasi mahasiswa pada 21 instansi publik di Yogyakarta, penulis menyajikan gambaran ketersediaan pusat arsip pada gambar 1.

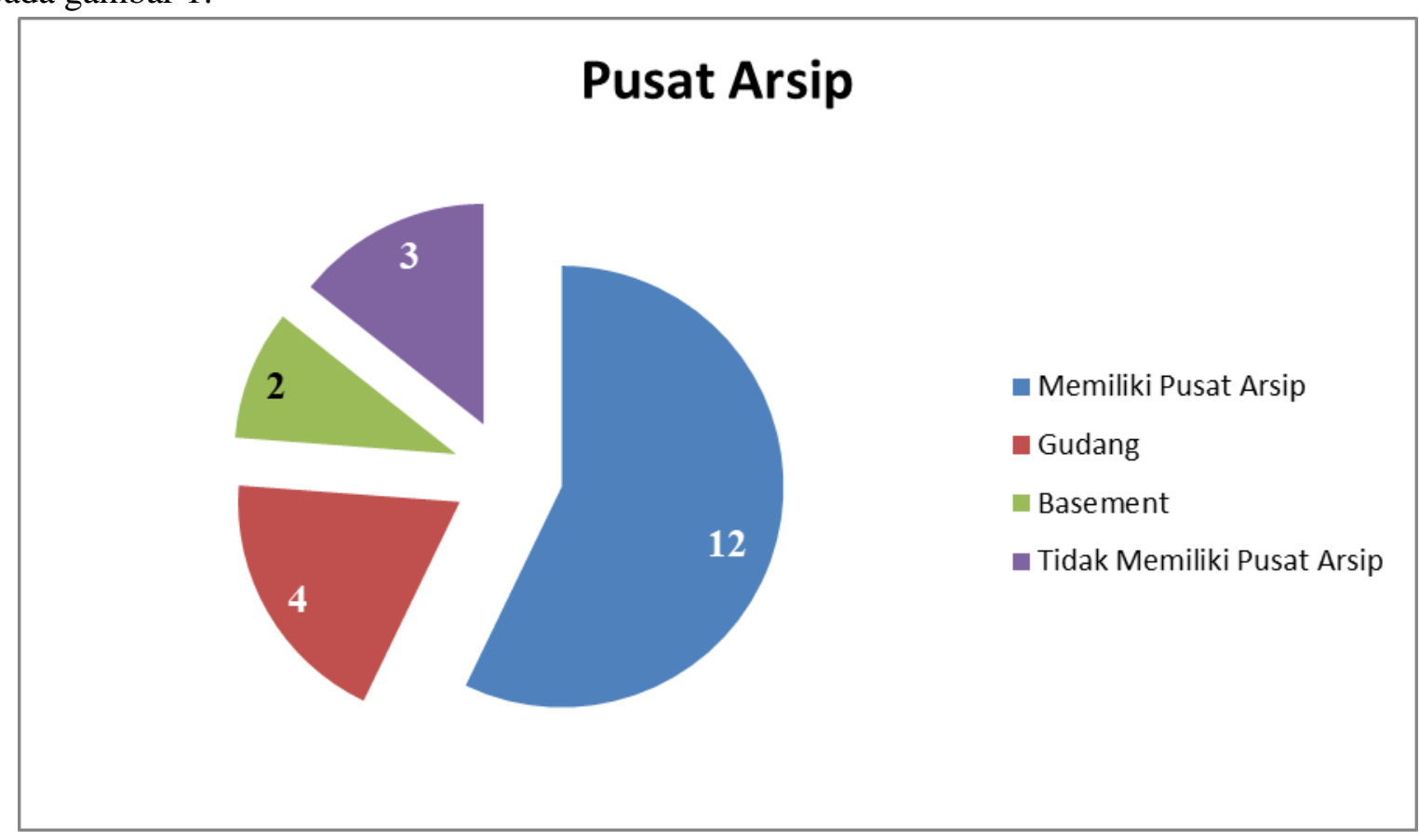

Gambar 1

Ketersediaan Pusat Arsip di Instansi Publik Yogyakarta

Sumber: Data Observasi Mahasiswa D3 Kearsipan angkatan 2016 dan 2017

Pada gambar 1 disajikan gambaran umum terkait ketersediaan pusat arsip pada instansi publik yang di observasi. Hasil menunjukkan bahwa sebagian besar instansi memiliki tempat penyimpanan arsip inaktif yaitu pusat arsip, sedangkan sisanya menggunakan gudang penyimpanan, basement dan tidak memiliki pusat arsip. Instansi yang tidak memiliki pusat arsip 
(sebanyak 3 organisasi) mengungkapkan bahwa mereka menganut asas pengorganisasian secara desentralisasi. Asas desentralisasi memungkinkan pengelolaan arsip aktif dan inaktif pada masing-masing unit kerja (pengolah). Untuk lebih jelasnya, penulis sajikan ilustrasi dalam bagan 1 mengenai perbedaan asas desentralisasi dan kombinasi.

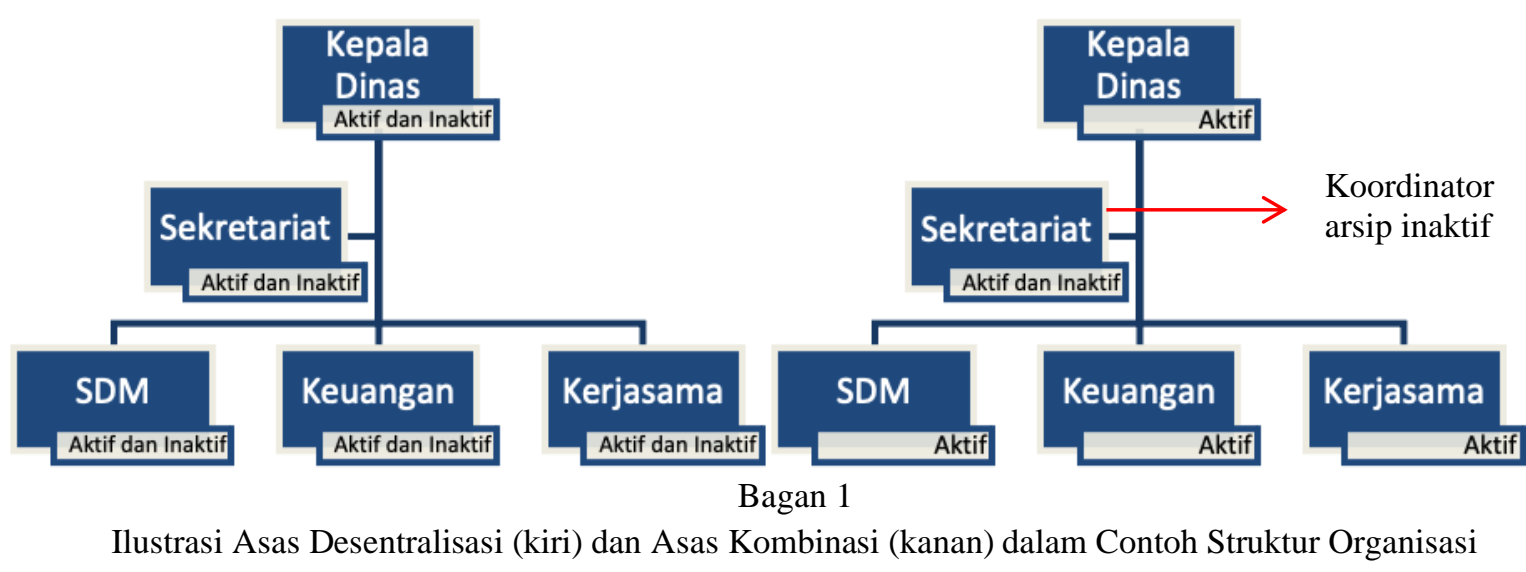

Ilustrasi dalam bagan 1 terkait asas pengorganisasian arsip menunjukkan posisi dan tanggung jawab dalam pengelolaan arsip aktif dan inaktif. Sebenarnya terdapat satu asas lagi yang tidak diilustrasikan yaitu asas sentralisasi. Asas sentralisasi tidak penulis temukan dalam objek penelitian. Asas sentralisasi merujuk pada pengelolaan arsip aktif dan inaktif pada satu unit kerja yang ditunjuk oleh organisasi. Sebagian besar instansi yang diobservasi menganut asas kombinasi, dimana arsip aktif menjadi tanggung jawab masing-masing unit kerja (desentralisasi arsip aktif), sedangkan arsip inaktif dikoordinir oleh satu unit tersendiri (sentralisasi arsip inaktif). Posisi pusat arsip akan berada dibawah wewenang dari satu unit tersebut. Beberapa instansi menggunakan istilah yang sama dalam menunjuk koordinator pusat arsip, namun ada pula yang menggunakan istilah berbeda. Pada instansi yang di observasi, unit kearsipan diserahkan pada sekretariat bagian umum, subbagian tata usaha, subbagian umum, bagian pemerintahan umum, subbagian umum dan kepegawaian, serta Subbagian Tata Persuratan dan Arsip di Biro Umum, Humas, dan Protokol.

Di bawah naungan unit kearsipan yang telah disebutkan diatas, kondisi tempat penyimpanan arsip inaktif bervariasi. Penulis akan mengulas kondisi tempat penyimpanan sesuai dengan kategori hasil observasi yaitu pusat arsip, gudang dan basement (tempat penyimpanan bawah tanah). Berikut disajikan tabel 2 mengenai analisis kondisi tempat penyimpanan arsip inaktif.

Tabel 2

Analisis Kondisi Umum Tempat Penyimpanan Arsip Inaktif berdasarkan Prinsip ANRI

\begin{tabular}{|c|c|c|c|}
\hline $\begin{array}{l}\text { Kondisi } \\
\text { Prinsip }\end{array}$ & Pusat Arsip & Gudang & Basement \\
\hline Murah & Memenuhi & Memenuhi & Memenuhi \\
\hline Luas & Memenuhi & Cukup Memenuhi & Memenuhi \\
\hline Keamanan & $\begin{array}{l}\text { Dipenuhi sarang } \\
\text { laba-laba, cahaya } \\
\text { masuk terlalu } \\
\text { banyak, akses orang } \\
\text { berlalu lalang, } \\
\text { banjir, rayap, } \\
\text { lembab }\end{array}$ & $\begin{array}{l}\text { Kelembaban, suhu, } \\
\text { cahaya }\end{array}$ & $\begin{array}{l}\text { Kotor, cahaya, } \\
\text { sirkulasi udara, } \\
\text { lembab, bocor }\end{array}$ \\
\hline Mudah Diakses & $\begin{array}{l}\text { Tercampur dengan } \\
\text { barang non arsip }\end{array}$ & Berantakan & Belum tertata \\
\hline
\end{tabular}


Penulis melakukan analisis kondisi tempat penyimpanan arsip inaktif pada 21 instansi publik berdasarkan prinsip yang disyaratkan oleh (Arsip Nasional Republik Indonesia, 2000). Empat kriteria yang harus dipenuhi dalam menyediakan tempat penyimpanan arsip inaktif meliputi murah, luas, keamanan dan kemudahan akses. Ditinjau dari aspek pembiayaan, tempat penyimpanan yang telah disediakan oleh instansi publik yang di observasi memenuhi kriteria murah (berbiaya rendah). Hal ini karena sebagian besar organisasi menggunakan ruang yang telah ada baik berupa pusat arsip, gudang maupun basement. Luas ruang yang disediakan juga cukup untuk menampung arsip inaktif yang dimiliki oleh organisasi. Permasalahan muncul pada kriteria keamanan dan kemudahan akses. Dari segi keamanan, standar minimal gedung dan penyimpanan arsip inaktif (Arsip Nasional Republik Indonesia, 2000) mensyaratkan "penyimpanan arsip inaktif harus dapat menjamin keamanan dari gangguan manusia yang tidak berwenang, gangguan binatang dan gangguan alam termasuk iklim tropis." Tempat penyimpanan yang dipilih (baik pusat arsip, gudang dan basement) oleh objek penelitian ternyata belum memenuhi unsur keamanan. Pada pusat arsip, mahasiswa menemukan kondisi pusat arsip yang dipenuhi sarang laba-laba, rayap, lembab, banjir hingga banyak orang dapat dengan mudah memasuki pusat arsip. Tempat penyimpanan di gudang juga memiliki permasalahan sendiri yang mengancam keamanan arsip meliputi kelembaban, suhu dan cahaya. Di basement, mahasiswa mendapati kondisi tempat penyimpanan yang kotor, lembab, bocor, sirkulasi udara dan cahaya yang tidak memadai.

Berdasarkan hasil yang telah dipaparkan, dapat disimpulkan bahwa kondisi pusat arsip secara umum pada instansi publik yang di observasi masih belum ideal. Hal ini dapat mempengaruhi kecepatan dan ketepatan instansi publik dalam menyediakan informasi yang dibutuhkan oleh instansi itu sendiri maupun masyarakat. Pada tabel 2, penulis sajikan hasil analisis berdasarkan prinsip kemudahan akses. Hasil menunjukkan bahwa akses terhadap arsip yang dibutuhkan menjadi tidak mudah untuk dilakukan karena kondisi arsip yang belum tertata, berantakan dan tercampur dengan barang non-arsip. Berikut disajikan pada gambar 2 dan 3 mengenai kondisi tempat penyimpanan arsip inaktif.

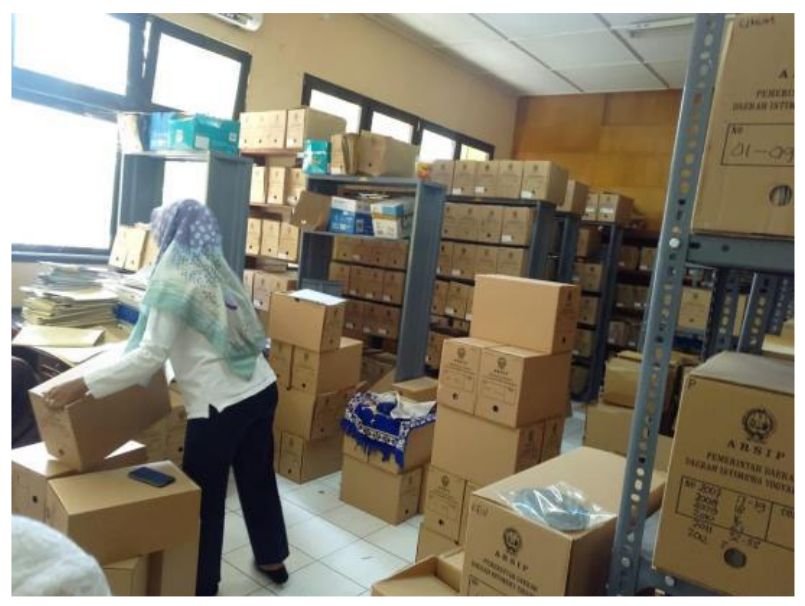

Gambar 2

Kondisi Tempat Penyimpanan Arsip pada Instansi X Sumber: Makalah Kelompok (Annissa, 2019) 


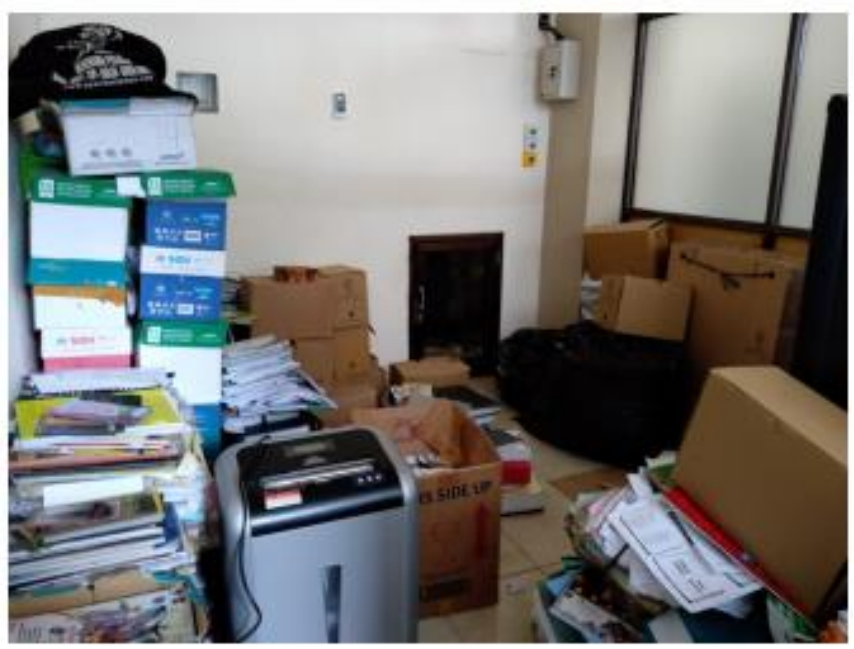

Gambar 3

Kondisi Tempat Penyimpanan pada Instansi Y

Sumber: Makalah Kelompok (Yuniastriana, 2019)

Berdasarkan gambar 2 dan 3 dapat diketahui kondisi umum tempat penyimpanan arsip pada instansi yang telah di observasi cukup memprihatinkan. Permasalahan pengelolaan arsip yang ada pada pusat arsip dapat berdampak luas apabila tidak kunjung ada upaya perbaikan. Instansi publik memiliki tanggung jawab dalam penyelamatan aset negara, pelayanan kepada masyarakat dan beberapa fungsi krusial lain yang melekat pada instansi tersebut. Hilangnya informasi yang dibutuhkan negara dan masyarakat dapat merugikan negara dan menghilangkan hak masyarakat sebagai warga negara.

\section{Tantangan Relevansi: Peralihan Pusat Arsip menjadi Pusat Data}

Kondisi pusat arsip yang telah dipaparkan sebelumnya, meninggalkan pertanyaan besar apakah pusat arsip dapat menjadi relevan di era digital? Para pemerhati, akademisi dan arsiparis memerlukan upaya tertentu untuk menjawab tantangan relevansi pusat arsip dalam dunia kearsipan saat ini. Tidak dapat dipungkiri, setiap organisasi saat ini telah menghasilkan arsip dengan media baru yaitu arsip elektronik. Hal ini ditengarai oleh massifnya penggunaan komputer dan perangkat teknologi oleh pengguna perseorangan maupun instansi. (Dhani Sugiharto, 2010) mengungkapkan bahwa teknologi informasi menghadirkan peluang bagi instansi pemerintah dalam memberikan pelayanan kepada publik. Peluang ini dapat dimanfaatkan dengan baik oleh lembaga publik apabila instansi dapat melakukan pengolahan memadai pada beragam jenis arsip elektronik yang dimiliki. Faktanya, instansi publik saat ini tidak bisa lepas dari penggunaan teknologi dan menghasilkan arsip elektronik. Hasil interview dengan penanggung jawab pengelolaan informasi di Biro Organisasi Pemerintahan, Sekretariat Daerah dan Badan Kepegawaian Daerah tingkat Provinsi DIY, menunjukkan beberapa jenis arsip elektronik yang tersaji pada tabel 3 .

Tabel 3

Arsip Elektronik yang dimiliki oleh Instansi Publik yang di Observasi

\begin{tabular}{llll}
\hline & Biro Organisasi & BKD & Biro Umum \\
\hline Database & Ada & Ada & Ada \\
Jurnal Akademik & - & - & - \\
Website & Ada & Ada & Ada \\
Email & Ada & Ada & Ada \\
Foto Digital & Ada & Ada & Ada \\
Arsip Audiovisual & Ada & - & Ada \\
\hline
\end{tabular}


Berdasarkan data yang disajikan pada tabel 3, menunjukkan bahwa instansi publik yang menjadi objek penelitian telah menghasilkan arsip elektronik dalam bentuk database, website, komunikasi email, foto dan media audiovisual lainnya. Jenis arsip elektronik yang dihasilkan oleh instansi publik, perlu dijamin ketersediaannya agar aktivitas organisasi dapat berjalan dengan lancar. Ketersediaan informasi berarti bahwa orang (pekerja, pelanggan, pemasok dan rekan bisnis) dapat mengakses informasi kapanpun mereka membutuhkannya (EMC Education Services, 2012).

Urgensi ketersediaan informasi elektronik inilah yang melahirkan kebutuhan khusus akan tempat penyimpanan informasi. Selama beberapa dekade terakhir, tempat penyimpanan informasi dikembangkan dengan teknologi yang lebih canggih, menyediakan bermacam solusi untuk menyimpan, mengelola, menghubungkan, melindungi, mengamankan, berbagi, dan mengoptimalisasikan informasi digital (EMC Education Services, 2012). Oleh karena itulah, pusat arsip konvensional yang mulai beralih menjadi pusat data menjadi alternatif untuk menjawab tantangan relevansi. Pusat data (data center) merupakan fasilitas yang berisi tempat penyimpanan informasi dan sumber daya fisik teknologi informasi seperti komputer, jaringan dan penyimpanan informasi (EMC Education Services, 2012). Pusat data ini menjadi pilar penting dalam menjaga keamanan dan menjamin ketersediaan arsip elektronik. Dampak yang harus dihadapi oleh organisasi apabila informasi yang dibutuhkan tidak tersedia yaitu produktivitas, pendapatan, berkurangnya kinerja keuangan dan merusak reputasi organisasi (EMC Education Services, 2012).

Pusat data memiliki kontribusi dalam mendukung ketersediaan arsip elektronik, namun tempat penyimpanan ini tidak lepas dari resiko yang harus dihadapi. (Dhani Sugiharto, 2010) mengungkapkan bahwa terdapat beberapa resiko dalam penyimpanan arsip digital yaitu migrasi dan keusangan format tempat penyimpanan informasi. Resiko ini menghadirkan tantangan bagi pusat data dalam pelestarian fisik dan isi informasi arsip elektronik jangka panjang. Pengelola perlu memahami proses migrasi arsip sesuai dengan format penyimpanan informasi terbaru, tanpa kehilangan isi informasi yang ada didalamnya. Berdasarkan hasil wawancara mendalam dengan informan (biro organisasi, BKD dan biro umum), ketiga instansi publik ini telah memiliki dan mempersiapkan tempat penyimpanan elektronik karena kepentingan pusat data bagi instansi.

Pusat data dan pengelolaan arsip elektronik secara keseluruhan, menjadi elemen penting untuk meminimalisir dampak kerusakan dan hilangnya akses informasi. Fungsi pusat data yaitu menjadi back up dalam pemenuhan kebutuhan operasional sehari-hari (sesuai dengan retensi) serta recovery ketika terjadi bencana. Secara spesifik, back up memiliki 3 tujuan yaitu pemulihan pasca bencana, pemulihan operasional dan pengarsipan (EMC Education Services, 2012). Apabila terjadi bencana pada lokasi utama penyimpanan, copy back up pada lokasi lain dapat menyediakan kembali data yang dibutuhkan. Selain itu, pada kegiatan operasional sehari-hari terdapat kemungkinan data rusak atau hilang selama digunakan, back up dapat menjadi alternatif cadangan data. Yang terakhir, back up digunakan untuk memenuhi kebutuhan pengarsipan arsip elektronik sesuai dengan regulasi.

Pada akhirnya, relevan atau tidaknya pusat data bagi instansi publik di era digital, dapat dilihat dari keberhasilan pusat data mengakomodir kebutuhan manajemen dan menyediakan informasi bagi pengguna. Indikator keberhasilan dalam pemenuhan informasi terdiri dari aksesbilitas, realibilitas dan waktu akses informasi (EMC Education Services, 2012). Aksesbililitas berarti informasi dapat diakses pada waktu yang tepat, oleh pengguna yang tepat dan di tempat yang tepat. Reabilitas merujuk pada informasi yang disimpan merupakan informasi yang original (tidak terjadi kerusakan maupun pergantian isi informasi). Indikator terakhir yaitu waktu, sehingga informasi dapat disajikan dengan cepat. Pusat data menjadi bagian yang tidak dapat dipisahkan dalam tata kelola informasi elektronik. Pengelola informasi di era digital, idealnya mempersiapkan pusat data yang dapat mengakomodir kebutuhan instansi dan pengguna. 
Hal ini akan berdampak secara luas dalam pelestarian arsip elektronik agar dapat terakses dari waktu ke waktu.

\section{Mengambil Langkah: Strategi dalam Menghadapi Tantangan Perubahan}

Pengelola arsip di era digital menghadapi dilema dalam manajemen pusat arsip sebagai upaya penyelamatan arsip berbagai format. Pusat arsip konvensional pada instansi publik yang diobservasi menemui kendala keamanan arsip dan kesulitan temu kembali arsip. Hal ini merupakan dampak dari penggunaan ruang penyimpanan arsip yang belum memadai, termasuk ditemukannya basement dan gudang pada beberapa instansi publik. Di sisi lain, kemunculan teknologi menghadirkan tantangan baru berhubungan dengan kebutuhan tempat penyimpanan arsip elektronik yang umum disebut pusat data (data center).

Langkah strategis untuk menyelesaikan permasalahan dan menjawab tantangan, harus penulis akui bukanlah hal yang mudah untuk diberikan. Pusat arsip yang memiliki keragaman media simpan informasi, perlu mendapat perhatian sebagai upaya pelestarian jangka panjang dari berbagai arsip yang dimiliki. Berdasarkan permasalahan yang terjadi pada instansi publik di Yogyakarta, penulis mengusulkan pendekatan manajemen untuk penyelesaian masalah pengelolaan arsip konvensional yaitu evaluasi dan perencanaan.

Penulis menggunakan tahapan awal berupa evaluasi dengan memprioritaskan penyelamatan arsip konvensional pada pusat arsip. Hal ini mengingat permasalahan penggunaan sarana prasarana yang telah ada pada instansi publik yang diobservasi. Instansi publik perlu melakukan evaluasi terhadap pengelolaan arsip secara keseluruhan dan mengidentifikasi sumber permasalahan. Evaluasi dan identifikasi masalah merupakan upaya refleksi instansi, sehingga dapat memahami dengan lebih dalam karakter instansi masing-masing beserta sumber daya yang dimiliki. Proses ini memang membutuhkan komitmen besar dari pejabat publik, namun bertujuan untuk membangun kesadaran akan pentingnya pengelolaan arsip secara keseluruhan. Adapun beberapa hal yang perlu dijawab dalam proses evaluasi di pusat arsip adalah: (1) Sejauh mana pusat arsip yang dimiliki dapat mengakomodir kebutuhan penyimpanan arsip dalam beragam format? (2) Apakah pusat arsip telah memiliki infrastruktur memadai, sumber daya manusia yang kompeten, kebijakan, prosedur pelaksanaan kegiatan dan perangkat pendukung lainnya? (3) Apakah pusat arsip memiliki sumber daya keuangan yang cukup untuk melaksanakan tugas pengelolaan informasi pada instansi publik? (4) Bagaimana program kerja yang ada terlah terimplementasi di pusat arsip? (5) Elemen apa saja yang harus diperbaiki di masa mendatang?

Berdasarkan hasil evaluasi dan identifikasi masalah yang ada di pusat arsip, instansi publik kemudian dapat menyusun strategi yang tertuang dalam perencanaan kegiatan di pusat arsip konvensional dan pusat data. Dalam proses perencanaan, instansi publik juga perlu merumuskan tujuan dan arah pengembangan dalam pengelolaan kearsipan secara keseluruhan. Berikut tersaji pada gambar 4 terkait elemen yang dapat dipersiapkan dalam pusat arsip dan pusat data. 


\section{Past}

Record

Center
Future

Data

Center



Gambar 4

Elemen Perencanaan dalam Pusat Arsip dan Pusat Data

Berdasarkan gambar 4, instansi publik membutuhkan pusat arsip konvensional dan pusat data. Hal ini mengingat masih terciptanya arsip yang bermedia kertas disertai dengan permasalahan yang ada pada pengelolaan arsip konvensional. Disamping itu, instansi publik juga sudah menciptakan arsip elektronik dalam berbagai bentuk yang perlu dikelola untuk kemudahan akses dan kelestarian dimasa yang akan datang. Oleh karena itulah, saat ini pengelola arsip perlu mempersiapkan beberapa hal yang dibutuhkan oleh pusat arsip dan pusat data.

Pada pusat arsip konvensional, diperlukan prosedur, kebijakan, sumber daya manusia, infrastruktur dan pendanaan. Pertama, prosedur yang jelas dalam manajemen pusat arsip dapat disusun agar memudahkan pengelola arsip dalam menjalankan tugas dan menjadi acuan kerja terstandar. Kedua, dukungan manajemen (tingkat menengah dan atas) yang tertuang dalam kebijakan dapat memberikan sumbangsih dalam membangun komitmen dan kesadaran seluruh elemen yang ada di instansi publik. Ketiga, sumber daya manusia yang mumpuni dengan latar belakang keilmuan dan pelatihan kearsipan menjadi elemen penting dalam perencanaan. Keempat, infrastruktur yang dibutuhkan dalam penyimpanan arsip konvensional perlu dirancang, misalnya rak, boks, roll o 'pact, meja pengolah, kursi pengolah, pengatur suhu (AC), pengatur kelembaban (dehumidifier), alat pengukur suhu dan kelembaban (thermohygrometer) hingga peralatan penanganan bencana (sprinkler, fire extinguisher dsb) serta pembasmi serangga. Kelima, pendanaan menjadi elemen krusial dalam proses perencanaan pada instansi publik. Pendanaan diperlukan untuk menjalankan program, pembelian infrastruktur hingga honorarium sumber daya manusia yang ada dalam pusat arsip konvensional. Apabila dalam pusat arsip ditemukan format media penyimpanan arsip selain kertas, maka sarana penyimpanan yang sesuai perlu diadakan. Misalnya, arsip kartografi memerlukan vertical plan dan horizontal plan, arsip foto memerlukan amplop khusus foto, beserta media yang lain yaitu kaset, CD, microfilm, dsb.

Selaras dengan perencanaan pada pusat arsip konvensional, arsiparis juga perlu untuk membuat perencanaan pada pusat data. Hal ini mengingat perubahan cara kerja arsiparis dan tuntutan pengguna dalam layanan kearsipan. Para pengelola informasi dan arsip diharapkan dapat mempertimbangkan tujuan jangka panjang dan layanan yang disajikan (Phillips, 1993). 
Pergesaran pusat arsip menjadi pusat data membutuhkan perencanaan matang dari instansi publik dengan memperhatikan budaya digital, kebijakan dan prosedur, hardware, brainware serta software. Hal ini senada dengan (Phillips, 1993) bahwa instansi publik memerlukan prosedur, staf, peralatan tambahan, pelatihan pegawai untuk merubah secara signifikan fokus layanan dari organisasi. Pertama, instansi publik perlu mempersiapkan dukungan terhadap budaya digital bagi para pegawai. Pegawai dibekali dengan kemampuan teknis dan keilmuan untuk beradaptasi dilingkungan digital dan memiliki literasi digital yang tinggi. Kedua, prosedur dan kebijakan dalam manajemen pusat data dirancang berdasarkan regulasi yang telah ada di Indonesia (Undang-Undang Informasi dan Tranksaksi Elektronik, Keterbukaan Informasi dan EGovernment) dan Internasional (ISO 15489: 2016). Ketiga, instansi publik membutuhkan hardware berupa perangkat komputer, perangkat jaringan dan perangkat penyimpanan (server). Apabila infrastruktur fisik sulit untuk diakomodir, instansi publik dapat menggunakan cloud yang dirancang oleh BUMN Indonesia. Keempat, perencanaan pengelola data yang handal diperlukan oleh instansi publik dengan memperhatikan latar belakang keilmuan seperti teknologi informasi, sistem informasi. Pengelola data nantinya akan bekerja sama dengan arsiparis dan pengelola informasi dalam manajemen arsip elektronik. Kelima, pusat data perlu didukung software yang terus diupdate sesuai kebutuhan pengguna.

Pengelola pusat arsip pada lembaga publik di era digital menghadapi tantangan besar dalam mempersiapkan kebutuhan manajemen arsip berbagai format. Ketika pusat arsip memiliki media yang beragam, baik bentuk digital maupun analog, pekerjaan pelestarian memerlukan proses berkesinambungan dalam memindahkan konten dari media lama ke media baru (Dhani Sugiharto, 2010). Resiko tidak dapat teraksesnya arsip akan lebih besar jika pengelola informasi tidak melakukan migrasi format penyimpanan pada media penyimpanan baru. Di luar resiko internal yang muncul, resiko bencana, penyalahgunaan dan kebocoran informasi juga membayangi pusat arsip maupun data. Hal ini senada dengan pendapat (Lowe, Davis, \& Green, 2016) bahwa teknologi informasi berhadapan dengan resiko keamanan, kesesuaian dengan regulasi dan kontrol terhadap bisnis secara keseluruhan. Oleh karena itulah, pusat arsip dan pusat data membutuhkan dukungan dari setiap elemen yang ada di instansi publik disertai dengan kontrol lingkungan yang memadai. Hal ini dijelaskan pula pada (International Standard Organization, 2016) bahwa penyimpanan arsip, termasuk lingkungan dan media, perlindungan materi, prosedur penanganan dan sistem penyimpanan seharusnya dimonitor dan dievaluasi secara rutin dalam pemenuhan proses identifikasi resiko aksesbilitas atau integritas arsip dinamis.

\section{SIMPULAN}

Tempat penyimpanan arsip pada 21 lembaga publik yang diobservasi dalam kondisi beragam. Sebagian besar institusi publik telah memiliki pusat arsip, beberapa lainnya menggunakan gudang, basement dan tidak memiliki tempat penyimpanan arsip konvensional. Posisi pusat arsip yang kurang mendapat perhatian, berdampak pada keamanan dan temu kembali arsip. Permasalahan keamanan ini memiliki resiko kehilangan dan kerusakan fisik arsip yang dimiliki oleh instansi publik. Begitupula kesulitan temu kembali arsip akan mempengaruhi layanan instansi kepada publik. Oleh karena itulah, pusat arsip konvensional perlu mendapat perhatian dan upaya perbaikan secepatnya.

Fakta bahwa pusat arsip dalam kondisi kurang "ideal", berbanding terbalik dengan kepentingannya di era digital. Instansi publik di era digital memerlukan pusat arsip dan pusat data untuk memenuhi tuntutan pengguna akan kemudahan dan kecepatan akses informasi publik. Relevansi pusat arsip ditentukan oleh kemampuan beradaptasi dan berubah dalam penyediaan tempat penyimpanan arsip elektronik. Peralihan pusat arsip menjadi pusat data menjadi suatu hal yang tidak dapat dihindarkan lagi. Pusat data diharapkan dapat menyelamatkan arsip dalam 
jangka waktu tertentu karena fungsinya sebagai back up dalam kegiatan operasional, pengarsipan dan pemulihan bencana.

Pengelola arsip perlu mengambil langkah strategis dalam penyelamatan arsip dalam berbagai format yang dihasilkan lembaga publik. Saat ini, instansi publik menghasilkan informasi dalam berbagai format dengan media penyimpanan yang beragam. Posisi pengelola arsip berada ditengah antara persiapan rancangan pusat data dan penyelesaian masalah media sebelumnya dipusat arsip. Pusat arsip konvensional memerlukan beberapa hal yaitu prosedur, kebijakan, sumberdaya manusia, infrastruktur dan pendanaan yang sesuai. Tak luput dari itu, arsip elektronik di pusat data juga menanti perencanaan yang matang. Instansi publik membutuhkan dukungan budaya digital, kebijakan dan prosedur, hardware, brainware, dan software yang memadai dalam pengembangannya. Langkah strategis ini dapat dilakukan untuk penyediaan penyimpanan arsip sesuai dengan kebutuhan pengguna. Berbagai resiko dalam penyediaan akses informasi diharapkan dapat berkurang sebagai upaya mendukung tata kelola informasi publik yang baik (good government).

Pada ranah praktis, instansi publik diharapkan membangun komitmen dan mempersiapkan sumberdaya yang memadai untuk pusat arsip dan pusat data. Komitmen dan kesadaran yang dibangun bersama oleh semua elemen instansi akan berpengaruh pada tata kelola pusat arsip maupun pusat data. Penyediaan infrastruktur penyimpanan, prosedur, kebijakan dan sumber daya manusia perlu diupayakan untuk meminimalisir kesalahan dan dampak yang timbul dikemudian hari. Pada ranah akademis, kajian ini membahas permasalahan umum yang dihadapi pusat arsip di lembaga publik. Beberapa hal lebih mendalam terkait dengan upaya mengungkap permasalahan belum dapat ditemukan. Penelitian lebih lanjut diharapkan dapat menemukan lebih lanjut permasalahan produktivitas arsiparis, dukungan pimpinan dan sistem birokrasi pemerintahan. Selain itu, setting penelitian pada lokasi yang berbeda kemungkinan akan memperkaya kajian ini, misalnya pusat arsip dan data pada instansi swasta.

\section{DAFTAR PUSTAKA}

Annissa, A. (2019). Laporan Evaluasi Record Center di Instansi X. Yogyakarta.

Arsip Nasional Republik Indonesia. (2000). Keputusan Kepala Arsip Nasional Republik Indonesia Nomor 03 Tahun 2000 Tentang Standar Minimal Gedung Dan Ruang Penyimpanan Arsip Inaktif.

Arsip Universitas Gadjah Mada. (2014). Manajemen Arsip Inaktif sebagai Solusi Permasalahan Arsip Inaktif Tidak Teratur. Retrieved March 5, 2020, from http://arsip.ugm.ac.id/2014/08/18/manajemen-arsip-inaktif-sebagai-solusi-permasalahanarsip-inaktif-tidak-teratur/

Bungin, B. (2015). Penelitian Kualitatif (2nd ed.). Jakarta: Kencana.

Cox, R. J. (2011). Archival Anxiety and the Vocational Calling. Duluth: Litwin Books.

Dhani Sugiharto. (2010). Penyelamatan Informasi Dokumen/Arsip Di Era Teknologi Digital. Baca: Jurnal Dokumentasi Dan Informasi, 31(1), 51-64. https://doi.org/http://dx.doi.org/10.14203/j.baca.v31i1.96

EMC Education Services. (2012). Information Storage and Management: Storing, Managing, and Protecting Digital Information in Classic, Virtualized, and Cloud Environment. In S. Gnanasundaram \& A. Shrivastava (Eds.), 經濟研究 (2nd ed.). United States: Wiley.

Idris, M. (2019). Gedung Arsip BUMN, Digagas Rini Soemarno, Dikubur Erick Thohir. Retrieved April 4, 2020, from Kompas website: https://money.kompas.com/read/2019/12/14/180000826/gedung-arsip-bumn-digagas-rinisoemarno-dikubur-erick-thohir 
International Standard Organization. (2016). ISO 15489-1: Information, documentation and Records Management. 2016.

Jumiyati, E. (2011). Sarana dan prasarana kearsipan di pusat teknologi bahan bakar nuklir batan. Majalah Ilmiah Pengelolaan Instalasi Nuklir, (07), 60-69.

Kwak Kun-Hong. (2011). Revaluation of the Records Center System in Korea. Korean Journal of Archival Studies, (27), 3-33. https://doi.org/10.20923/KJAS.2011.27.003

Lowe, S. D., Davis, D. M., \& Green, J. (2016). Building a Modern Data Center: Principles and Strategies of Design (1st ed.; H. Kirchner \& Dream Write Creative, Eds.). United States: ActualTech Media.

Patricia C. Franks. (2013). Records \& Information Management. US: American Library Association.

Phillips, J. T. (1993, January). Electronic vaulting and records centers. ARMA Records Management Quarterly, 38-49.

Ramanda, R. S., \& Indrahti, S. (2015). Analisis Pengelolaan Arsip Inaktif Terhadap Temu Kembali Arsip Di Pusat Arsip (Record Center) Politeknik Negeri Semarang. Jurnal Ilmu Perpustakaan, 4(3).

Sari, I. N. (2017). Perencanaan Record Center Sekolah Vokasi UGM (Analisis Kebutuhan, Rancangan dan Desain Untuk Teaching Industry). Diplomatika, 1, 12-23.

Yuniastriana, K. (2019). Laporan Observasi di Instansi Y (Vol. 1). Yogyakarta. 